\title{
FINANCING SLUM CLEARANCE
}

\author{
George W. WARNECKE*
}

Probably at no time in the history of this country has slum clearance housing been as much in the public eye as in recent months. Slums, defined as residential areas where houses and conditions of life are of such a squalid and wretched character as to make these areas social liabilities, must now be mopped up.

Success of the slum clearance housing projects built in recent years in England, Germany, Austria, Italy, and more recently in Russia, has brought to the fore the pitiful lack of thought which has been given to this subject in our own country. The inadequacy of this type of housing in the United States has been repeatedly shown by surveys made by competent agencies. Among other facts these show that new housing construction in the larger American cities over the past two decades has been principally for that 30 per cent of the population which receive the largest incomes. The remaining 70 per cent of the population, particularly those in the lowest-income groups, have to make the best of the antiquated and obsolete properties cast off by the more fortunate families.

To better understand this problem of financing slum clearance a review of what has previously taken place may be helpful. In times past when private business found that a small surplus in housing had been created for this uppermost $3^{\circ}$ per cent of the population, then further construction became unprofitable. Further, when it became apparent that this surplus was not readily absorbable over a short period of time, there was an immediate downward trend in rentals. This downward trend caused the lending agencies to become more conservative, and as a consequence practically all private construction stopped.

Cycles revolve slowly-even these limited surpluses are infrequent. The small and occasional surplus intended to satisfy the demand of only $3^{\circ}$ per cent of the population represents all that private business ever provided to meet the constantly increasing demands of the remaining 70 per cent of population.

The permanence of this problem of adequate housing for the bulk of people who are in the low-income group is apparent to anyone who makes even a cursory in-

- E.E., Kansas University, graduate engineering work, Heidelberg University, law and business adminstration; Columbia University. Executive on real estate investments, property construction and management for many nationally-known mortgagees and property owners throughout the country. Drafted by the Government as advisor on mortgage financing and real estate problems. Author of publications on real catate finance and operations. 
spection of the housing field. However, in spite of the impossibility of obtaining funds for slum clearance construction today through normal channels, or of having private business provide such construction, it is increasingly apparent that low-cost housing construction must go ahead. Throughout the country in the larger cities there exist old, dilapidated buildings which the general public has been made greatly aware of as incubators for diseases and crime. They have determined that such rookeries must be replaced with adequate housing facilities.

Private business has never made the attempt in any appreciable way to supply adequate housing to meet the needs of the great bulk of population in the lowerincome groups. In fact the very motive of profit which causes private business to enter the construction field mitigates against any low-cost housing being constructed.

Financial requirements for large-scale slum clearance operations do not differ in kind from those necessary to complete any program of dwelling construction. The forms of financing, however, need to be adapted to secure the following benefits:

(a) Basic mortgage money must be available in large sums.

(b) It must be available at lowest possible interest rates.

(c) Amortization must cover a long period.

(d) Equity money, if any, without high discounts or high rate of return must be available.

The financial problems connected with operations of this type can probably best be shown by example. For instance, let us consider the following facts which apply to the rehabilitation of slum areas in one of our largest midwestern cities-

r. Size of site-3,036,40r square feet

2. Estimated population to be rehoused on this site- -3600 families

3. Average number of persons per family- 4.9

4. Estimated cost of site-\$r.35 per square foot

5. Estimated cost of building construction-\$0.33 per cubic foot

6. Number of cubic feet of building required per rentable room-2050 cubic feet

7. Operating costs per rentable room- $\$ 3.00$ per room per month

8. Taxes (normal rates) $\$$ - 50 per room per month

9. Present average rental rates of families resident in slum areas $-\$ 6.50$ per room per month

I0. Amortization rates to liquidate a loan in 33 years- $-5.5 \%$

II. Interest rates assumed to be- $4 \%$

Based on the above the following monthly rental minimum is possible-

Operating Cost $\ldots \ldots \ldots \ldots \ldots \ldots \ldots \ldots \ldots \ldots \ldots \ldots \ldots 3.00$ per room per month

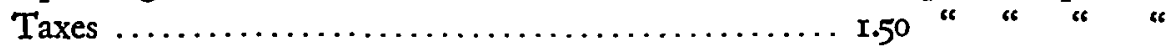

Interest on land and building cost ........... " " " " " " "

Amortization on building cost................ " .85 " " "

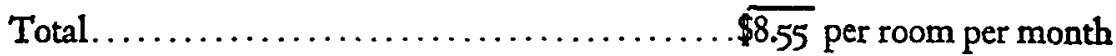


Thus under favorable conditions of cheap money and low land cost the rental per room per month is $\$ 8.55$ compared with an average rental rate of $\$ 6.5^{\circ}$ per room per month for the present slum residents.

Efforts made thus far to replace the slum dwellers in our larger cities in adequate housing facilities gives little reason to hope that this can be done through the traditional methods of realty financing. To circumvent some of the obstacles many proposals have been made for Government aid or for aid by foundations or other private sources. Some of these are-

Government-built housing-Federal, State, Municipal

Government grants and loans to Public Authorities for housing purposes

Government loans to limited-dividend housing corporations

Partnership between Public Housing Authorities and private enterprise

Private finance corporations, organized with funds supplied by building material manufacturers, labor unions, foundations or individuals to supply funds for housing operations

Breakdown of the free mortgage market-the drying up of the sources of loanable funds for housing - has been followed by the announcements that federal government agenciès will make direct loans for housing. As a' consequence projects have been considered in various parts of the country in the list two years, first, by the Reconstruction Finance Corporation and, later, by the Public Works Administration, having in mind the provision of equity money by the promoters against loans by these government agencies, the entire operations to be carried on under a state housing authority with limitations as to the dividends payable to the equity holders. In addition, direct loans plus $3^{\circ}$ per cent grants on labor and materials were made available to municipalities having adequate legislation to supervise housing projects.

Since private equity money able to meet the requirements of the government is practically non-existent at the present time, the government recently determined upon the policy of entering the slum clearance field directly in the rôle of a real estate operator. The government agency for this operation is the new Public Works Emergency Housing Corporation.

The government in thus participating directly in the slum clearance operations goes far beyond its usual regulatory practice. Whereas in prior times in various states the government (I) provided tax exemption for certain fixed periods; (2) publicly financed utilities installations; (3) provided access to new housing by publicly financing systems of transportation; (4) granted the right of eminent domain to condemn the property; (5) extended tax exemption privileges to housing corporations which limit their dividends, or their rents, or both, now it directly hurdles many of the financial obstacles which beset the carrying out of a slum clearance program.

More necessary than all other requirements for the replacement of slums with 
adequate housing is a plentiful supply of money at very low interest rates or some other financial arrangement which provides for low fixed charges on this type of development. The actual extent to which monies can be applied in this field can be readily appreciated through the statement that the elimination of slums through the construction of new housing could easily absorb in excess of five and one-half billions of dollars.

Any discussion as to the propriety or desirability of the government engaging in housing projects is academic. This is a condition-not a theory. The government is attempting to eradicate slum areas and provide low-cost housing. Certainly better housing for all the people is a result to be hoped for. A better use for government funds either from a social standpoint or from the standpoint of creating employment can hardly be conceived. 